\title{
Breathing technique in pain and cognitive function: a systematic review of the literature
}

DOI: https://doi.org/10.17981/JACN.1.1.2020.02

\author{
Armando Solarte ${ }^{1}$, Juan Pablo Alzate-Granados ${ }^{1}$, \\ Pedro Javier López-Pérez ${ }^{1}$ \& Ernesto Barceló ${ }^{1}$
}

${ }^{1}$ Universidad de la Costa. Barranquilla (Colombia)
Correspondence:

\section{Armando Solarte \\ Universidad de la Costa. \\ Barranquilla (Colombia) \\ E mail: aseia18@me.com}

\begin{abstract}
Breathing techniques are key components of yoga, meditation and relaxation practices that are well known for reducing anxiety and improving overall well-being. To evaluate the efficacy of breathing techniques in pain and cognitive function. We conducted a literature review searching the main literature databases (medline, lilacs, Cochrane library) including randomized clinical trials. We assessed the risk of bias of the included studies using the methodology proposed by the Cochrane collaboration. In total, we found 16 studies that met the inclusion criteria, with an intermediate or unclear overall risk of bias. When combining the different breathing techniques vs control in the included studies, we found a statistically significant difference in terms of the visual analog scale (Difference of means, random effects; -1.21 [95\% CI -1.75 to -0.68]; I2: 95\%). Meditation-based breathing techniques would improve pain and cognitive function in patients with a painful entity or healthy volunteers. Keywords: Breathing techniques; pain; cognitive function; systematic review; breath holding

\section{Técnicas respiratorias en dolor y función cognitiva: revisión sistemática de la literatura}

\section{Resumen}

Las técnicas de respiración son componentes clave de las prácticas de yoga, meditación y relajación que son bien conocidas por reducir la ansiedad y mejorar el bienestar general. Evaluar la eficacia de las técnicas respiratorias en el dolor y la función cognitiva. Realizamos una revisión de la literatura a través de las principales bases de datos especializadas (medline, lilacs, Cochrane library) incluyendo ensayos clínicos aleatorizados. El riesgo de sesgo de los estudios incluidos se evaluó mediante la metodología propuesta el Manual Cochrane para las Revisiones Sistemáticas. En total, encontramos 16 estudios que cumplieron con los criterios de inclusión, con un riesgo general de sesgo intermedio o poco claro. Al combinar las diferentes técnicas de respiración versus control en los estudios incluidos, se encontró una diferencia estadísticamente significativa en términos de la escala analógica visual (diferencia de medias, efectos aleatorios; -1,21 [IC del 95\%: -1,75 a -0,68]; I2: $95 \%$ ). Las técnicas de respiración basadas en la meditación mejorarían el dolor y la función cognitiva en pacientes con una entidad dolorosa o voluntarios sanos.

Palabras clave: Técnicas respiratorias; dolor; función cognitiva; revisión sistemática; contención de la respiración 


\section{INTRODUCTION}

Breathing techniques are key components of yoga, meditation, and relaxation practices that are well known for reducing anxiety and improving overall well-being (Arsenault, Ladouceur, Lehmann, Rainville \& Piché, 2013; Chan et al., 2019; Mah, Turgeon, Loh, Tejani \& Sweet, 2019; Mesgarpour et al., 2019). Slow breathing with focused attention to breathing is used in many interventions with the goal of inducing a state of relaxation (Arsenault et al, 2013; Wall, Magee, Campbell \& Zed, 2019), including meditation (Warttig et al., 2019).

Slow and deep breathing techniques are also used in the treatment of many conditions such as stress, anxiety, panic disorder, and depression (Lewis et al., 2019; Zhang, Zhang, Grant, Wan, \& Li, 2018). In such studies, these breathing techniques were found to alleviate anxiety, depression, daily stress, post-traumatic stress, and illness-related stress. Among the proposed mechanisms, the contribution to calm and alertness driven by the parasympathetic system, the stress response system, the release of neuroendocrine hormones, and thalamic generators are found. On the other hand, it has also been found that the group of respiratory exercises has a decrease in anxiety and depression, however the number of leukocytes did not differ between the groups; these findings suggest that relaxation breathing exercises improve anxiety and depression levels in the general population and in patients who will undergo hematopoietic cell transplantation (Lewis et al., 2019; Zhang et al., 2018).

Buddhist (Anapama) meditation practices have focused more on developing mindfulness of breath (Sud et al., 2018; Vojislav,
Ramanathana \& Mishraa 2020). However, even these mindfulness-based meditative practices have been shown to modify the respiratory rate and cycle (Choo, Simons \& Sheikh, 2018; VojislavMaric, 2020). Suzuki Roshi, a practitioner of Zen Buddhism, describes this process: both the breathing and pulse will tranquilize afterwards a 5 or 10 minutes period of not being distressed by the mind (Connolly et al., 2018).

Many of these mind-body perceptionbased breathing techniques (Yoga, Reiki, Tai Chi, Quiqong) have also been used with some success to improve pain management (Aamann, Dam, Rinnov, Vilstrup \& Gluud, 2018) and in a variety of associated clinical situations. with acute pain such as labor (Pollok, van Agteren \& Carson-Chahhoud, 2018) or injections in children (Arsenault et al., 2013; Gilbert-Kawai, Mitchell, Martin, Carlisle \& Grocott, 2018).

For these reasons, it is necessary to carry out a review of the literature that evaluates the effectiveness of the different breathing techniques in pain management and the evaluation of cognitive function.

\section{Methodology}

Systematic review of the literature

Criteria for including articles in this review

\section{- Types of studies}

Randomized clinical trials were included. Cluster, crossover or before and after studies were excluded.

\section{- Types of participants}

Patients with any condition or pathology were included, as well as healthy participants 12 years of age and older. 


\section{- Types of interventions}

Any controlled breathing technique at any intensity or number of sessions.

\section{Outcomes}

Pain: Measured with any scale used in each study

Cognitive function: Including memory, attention and other measures of cognitive function measured in each study.

\section{Search methods to identify studies}

\section{- Electronic searches}

Studies meeting the inclusion criteria were identified in either English or Spanish.

Using a set of controlled and uncontrolled terms for "breathing techniques", "Pain" and "Cognitive function", with field labels (title and summary), proximity operators, and Boolean operators. Search strategies will be found in Appendix 1.

Specifically, the following databases were used:

- The Cochrane Central Register of Controlled Trials.

-(CENTRAL, Ovid platform): inception to present.

- MEDLINE ${ }^{\circledR}$, Ovid platform: inception to present.

- MEDLINE ${ }^{\circledR}$ In-Process \& Other Non-Indexed Citations.

- Ovid platform: inception to present.

- MEDLINE ${ }^{\circledR}$ Daily Update, Ovid platform: inception to present.

- EMBASE, embase.com platform: inception to present.
- LILACS, IAHx interface: inception to present.

\section{Data collection and analysis}

\section{- Selection of studies}

Evaluated the inclusion and exclusion criteria of all titles and abstracts found in the search strategy. All potentially relevant studies were evaluated in full text. The entire selection process was documented in a PRISMA flow chart.

\section{Data extraction and management}

An extraction format was designed for each study and collected the following information:

- Study design.

- Year of publication.

- Participants: characteristics.

- Number of participants in each group

- Loss to follow-up.

- Techniques used (intervention and control).

- Definition and frequency of outcomes in each group.

- Sources of funding.

\section{- Evaluation of risk of bias}

The risk of bias of the included studies was independently assessed using the Cochrane Collaboration's risk of bias assessment that evaluates random sequence generation, concealment, blinding of the intervention to the participant and patient advisor, loss to follow-up, reporting bias, and other biases. 


\section{- Effect measures}

The studies were combined in a metaanalysis if possible, in cases where the studies could not be combined, a narrative synthesis was performed. A mean difference with a $95 \%$ confidence interval was used.

\section{- Evaluation of heterogeneity}

Heterogeneity was assessed using an I2 and chi2 test, significant heterogeneity will be considered if it is greater than $40 \%$ in the $\mathrm{I} 2$ and the $\mathrm{p}$ value is less than 0.1 in the chi2.

\section{RESULTS}

\section{Search results}

When searching the different databases, we found a total of 1428 references, of which, when reviewed in text and abstract, a total of 29 eligible were left, which were read in full text, leaving 16 references included, of which 9 were combined in a meta-analysis (See Figure 1).

\section{Studies included}

In total, 16 randomized clinical trials were included that compared some breathing pattern versus control.

Controls used include sham breathing techniques, different breathing methods (Wongwilairat, Buranruk, Eungpinichpong, Puntumetakul \& Kantharadussadee-Triamchaisri, 2018) or social interaction (Ferreira, Tanaka, Santos-Galduroz \& Fernandes, 2015).

The two outcomes found in the studies were pain in labor (Boaviagem et al., 2017; Yuksel, Cayir, Kosan \& Tastan, 2017), pain in general, cognitive function in terms of memory, abstraction, flexibility and attention (Ferreira et al., 2015; Larkey, Roe, Smith \& Millstine, 2016) (See Table 1).

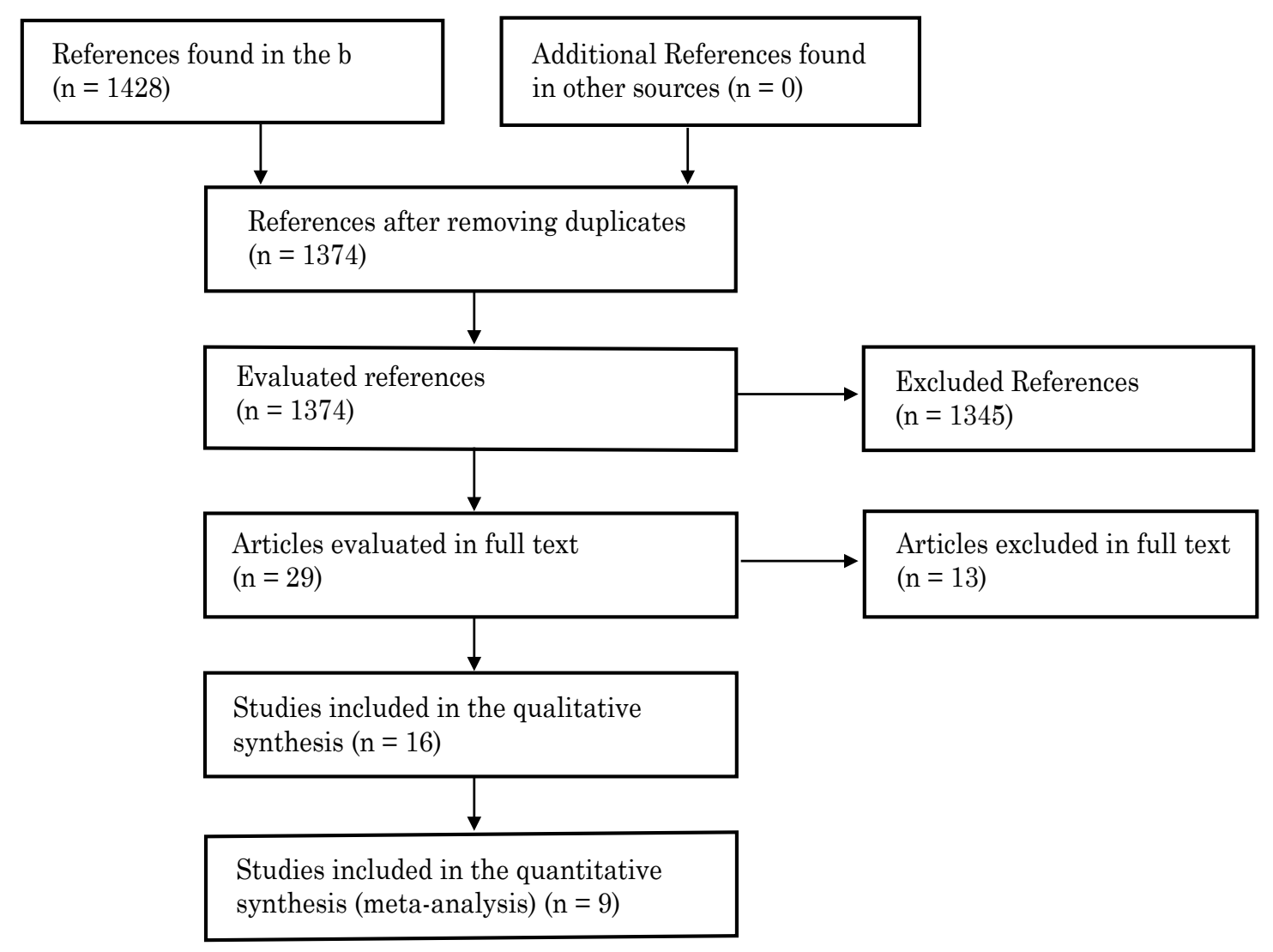

Figure 1. PRISMA flow chart. 
TABle 1.

Summary of included studies

\begin{tabular}{|c|c|c|c|c|c|c|c|}
\hline Reference & Population & Intervention & Comparator & Outcome & $\begin{array}{l}\text { Intervention } \\
\text { results }\end{array}$ & $\begin{array}{l}\text { Control } \\
\text { results }\end{array}$ & P-value \\
\hline \multirow{2}{*}{$\begin{array}{l}\text { Boaviagem, } 2016 \\
\text { (Boaviagem et al., 2017) }\end{array}$} & \multirow{2}{*}{$\begin{array}{l}\text { Women in labor, between } 12 \text { to } \\
40 \text { years old with a gestational } \\
\text { age between } 37 \text { and } 41 \text { weeks. }\end{array}$} & \multirow{2}{*}{$\begin{array}{l}\text { Breathing pattern. } \\
\mathrm{N}=67\end{array}$} & \multirow{2}{*}{ Control. $\mathrm{N}=73$} & Maternal anxiety & $50.6+/-1.8$ & $49.3+/-1.5$ & $\mathrm{NS}$ \\
\hline & & & & Maternal pain & $8.8+/-0.3$ & $8.8+/-0.3$ & NS \\
\hline $\begin{array}{l}\text { Yuksel, } 2017 \\
\text { (Yuksel et al., 2017) }\end{array}$ & $\begin{array}{l}\text { Pregnant women between } 37 \\
\text { to } 42 \text { weeks. }\end{array}$ & $\begin{array}{l}\text { Controlled } \\
\text { breathing. }(\mathrm{n}=125)\end{array}$ & $\begin{array}{l}\text { Control. }(\mathrm{N}= \\
125)\end{array}$ & Maternal pain & $88.2+/-6.3$ & $90.5+/-7$ & $\mathrm{P}=0.000$ \\
\hline $\begin{array}{l}\text { Tomas-Carus, } 2018 \\
\text { (Tomas-Carus et al., 2018) }\end{array}$ & Women with fibromyalgia & $\begin{array}{l}\text { Respiratory } \\
\text { exercise program } \\
\mathrm{N}=18\end{array}$ & Control. $\mathrm{N}=17$ & Pain & $\begin{array}{l}5.8 \\
(5.16 \text { a } 6.43)\end{array}$ & $\begin{array}{l}7.93(7.05 \text { to } \\
8.80)\end{array}$ & $p=0.025$ \\
\hline \multirow{2}{*}{$\begin{array}{l}\text { Saoji, } 2018 \\
\text { (Saoji, Raghavendra, Madle } \\
\text { \& Manjunath, 2018) }\end{array}$} & \multirow[b]{2}{*}{$\begin{array}{l}\text { Healthy volunteers for yoga } \\
\text { courses }\end{array}$} & \multirow{2}{*}{$\begin{array}{l}\text { Breath-based yoga } \\
\text { interventions } \mathrm{N}= \\
56\end{array}$} & \multirow[b]{2}{*}{ Control. $\mathrm{N}=56$} & $\begin{array}{l}\text { Mind-Wandering } \\
\text { Question-naire } \\
\text { (MWD) }\end{array}$ & $1.89+/-0.76$ & $2.41+/-0.89$ & $\mathrm{p}<0.01$ \\
\hline & & & & $\begin{array}{l}\text { State Mindfulness } \\
\text { Attention and } \\
\text { Awareness Scale } \\
\text { (SMAAS) }\end{array}$ & $4.27+/-0.75$ & $3.94+/-0.75$ & $\mathrm{p}<0.05$ \\
\hline $\begin{array}{l}\text { Wongwilairat, } 2018 \\
\text { (Wongwilairat et al., 2018) }\end{array}$ & $\begin{array}{l}\text { Women with tension neck pain } \\
\text { between } 20 \text { and } 25 \text { years old } \\
\text { with normal BMI }\end{array}$ & $\begin{array}{l}\text { Slow deep } \\
\text { breathing exercise. } \\
\mathrm{N}=8\end{array}$ & $\begin{array}{l}\text { Other breathing } \\
\text { methods } \mathrm{N}=8\end{array}$ & Pain & $0.75+/-0.71$ & $0.75+/-1.49$ & NS \\
\hline \multirow{2}{*}{$\begin{array}{l}\text { Grubić, } 2019 \\
\text { (Grubić, Babić \& Štimac, } \\
\text { 2019) }\end{array}$} & \multirow{2}{*}{ Multiple sclerosis patients } & \multirow{2}{*}{$\begin{array}{l}\text { Home-based } \\
\text { breathing exercise } \\
\mathrm{N}=9\end{array}$} & \multirow{2}{*}{ Control. $\mathrm{N}=9$} & $\begin{array}{l}\text { Pain-according to } \\
\text { sf36 outpatient }\end{array}$ & $80+/-27.4$ & $79.0+/-28.8$ & NS \\
\hline & & & & $\begin{array}{l}\text { Pain-according to } \\
\text { sf36 non-ambulatory }\end{array}$ & $72.5+/-28.5$ & $45.6+/-36.4$ & NS \\
\hline $\begin{array}{l}\text { Park, } 2019 \\
\text { (Park \& Lee, 2019) }\end{array}$ & $\begin{array}{l}\text { Low back pain patients aged } \\
18 \text { to } 65 \text { years with pain for at } \\
\text { least } 6 \text { weeks }\end{array}$ & $\begin{array}{l}\text { Breathing } \\
\text { resistance training } \\
\mathrm{N}=23\end{array}$ & Control. $\mathrm{N}=23$ & Pain- NRS & $3.6+/-1.14$ & $3.65+/-1.27$ & NS \\
\hline \multirow{2}{*}{$\begin{array}{l}\text { Tomas-Carus, } 2019 \\
\text { (Tomas-Carus et al., 2019) }\end{array}$} & \multirow{2}{*}{ Women with fibromyalgia } & \multirow{2}{*}{$\begin{array}{l}\text { Unsupervised } \\
\text { breathing exercise } \\
\text { program } \mathrm{N}=16\end{array}$} & \multirow{2}{*}{ Control. $\mathrm{N}=15$} & Pain tolerance & $1.58+/-0.38$ & $1.71+/-0.53$ & NS \\
\hline & & & & Pain & $6.8+/-1.69$ & $7.78+/-2$ & NS \\
\hline $\begin{array}{l}\text { Youn-Jung, } 2020 \\
\text { (Oh, Park \& Lee, 2020) }\end{array}$ & $\begin{array}{l}\text { Women with low back pain } \\
\text { between } 40 \text { to } 49 \text { years }\end{array}$ & $\begin{array}{l}\text { Abdominal } \\
\text { breathing } \\
\text { maneuvers. } \mathrm{N}=22\end{array}$ & Control. $\mathrm{N}=22$ & $\begin{array}{l}\text { Pain (Quadruple } \\
\text { Visual Analog Scale) }\end{array}$ & $4.58+/-0.46$ & $4.45+/-0.42$ & NS \\
\hline $\begin{array}{l}\text { Phattharasupharerk, } 2018 \\
\text { (Phattharasupharerk, } \\
\text { Purepong, Eksakulkla \& } \\
\text { Siriphorn, 2019) }\end{array}$ & $\begin{array}{l}\text { Office workers with non- } \\
\text { specific low back pain of at } \\
\text { least } 12 \text { weeks. Between } 20 \text { to } \\
40 \text { years of age. }\end{array}$ & Qigong $N=36$ & Control. $\mathrm{N}=36$ & Pain & $14+/-20.5$ & $53.5+/-20.9$ & $<0.001$ \\
\hline
\end{tabular}




\begin{tabular}{|c|c|c|c|c|c|c|c|}
\hline Reference & Population & Intervention & Comparator & Outcome & $\begin{array}{l}\text { Intervention } \\
\text { results }\end{array}$ & $\begin{array}{l}\text { Control } \\
\text { results }\end{array}$ & $\mathrm{P}$-value \\
\hline \multirow{2}{*}{$\begin{array}{l}\text { Peppone, } 2015 \\
\text { (Peppone et al., 2015) }\end{array}$} & \multirow{2}{*}{$\begin{array}{l}\text { Women cancer survivors } 2 \text { to } \\
24 \text { months post-surgery }\end{array}$} & \multirow{2}{*}{ YOCAS. $\mathrm{N}=75$} & \multirow{2}{*}{ Control. $\mathrm{N}=95$} & $\begin{array}{l}\text { Functional } \\
\text { Assessment of } \\
\text { Chronic Illness } \\
\text { Therapy with Fatigue } \\
\text { Subscale. Changes in } \\
\text { FACIT-F-I have pain }\end{array}$ & -0.18 & 0.04 & 0.021 \\
\hline & & & & $\begin{array}{l}\text { Multidimensional } \\
\text { Fatigue Symptom } \\
\text { Inventory-Short } \\
\text { Form. Changes } \\
\text { in MFSI-SF-my } \\
\text { muscles ache }\end{array}$ & -0.51 & -0.13 & 0.001 \\
\hline \multirow{8}{*}{$\begin{array}{l}\text { Ferreira, } 2015 \\
\text { (Ferreira et al., 2015) }\end{array}$} & \multirow{8}{*}{$\begin{array}{l}\text { Adults between } 60 \text { and } 79 \\
\text { years }\end{array}$} & \multirow{8}{*}{$\begin{array}{l}\text { Breathing training. } \\
\mathrm{N}=34\end{array}$} & \multirow{8}{*}{$\begin{array}{l}\text { Control (Social } \\
\text { interaction). N } \\
=34\end{array}$} & $\begin{array}{l}\text { Evocative / } \\
\text { declarative memory }\end{array}$ & $\begin{array}{l}21.0 \\
(18.5,23.6)\end{array}$ & $\begin{array}{l}25.4 \\
(22.7,28.1)\end{array}$ & NS \\
\hline & & & & Evocative memory & $\begin{array}{l}17.5 \\
(15.0,20.0)\end{array}$ & $\begin{array}{l}22.8(20.2 \\
25.4)\end{array}$ & NS \\
\hline & & & & Semantic memory & $\begin{array}{l}28.3 \\
(24.6,32.0)\end{array}$ & $\begin{array}{l}38.5 \\
(34.6,42.3)\end{array}$ & 0.01 \\
\hline & & & & Short term memory & $5.2(4.8,5.8)$ & $5.0(4.5,5.5)$ & NS \\
\hline & & & & Mental manipulation & $4.2(3.8,4.8)$ & $4.1(3.7,4.7)$ & 0.03 \\
\hline & & & & Abstraction & $4.8(4.2,5.5)$ & $4.0(3.3,4.7)$ & 0.01 \\
\hline & & & & Mental flexibility & $3.7(1.8,5.7)$ & $6.0(4.0,8.0)$ & 0.02 \\
\hline & & & & Attention & $\begin{array}{l}25.7 \\
(22.9,28.5)\end{array}$ & $\begin{array}{l}22.0 \\
(19.1,25.0)\end{array}$ & NS \\
\hline $\begin{array}{l}\text { Sagkal, } 2015 \\
\text { (Sagkal \& Eser, 2015) }\end{array}$ & $\begin{array}{l}\text { Women with cesarean delivery } \\
\text { between the ages of } 18 \text { and } \\
45 \text { who do not use non-opioid } \\
\text { analgesics. }\end{array}$ & Reiki. $N=50$ & Control. $\mathrm{N}=50$ & Pain & $1.24+/-0.99$ & $3.76+/-1.61$ & 0.001 \\
\hline $\begin{array}{l}\text { Telles, } 2016 \text { (Telles, } \\
\text { Sharma, Gupta, Bhardwaj } \\
\text { \& Balkrishna, 2016) }\end{array}$ & $\begin{array}{l}\text { People with degenerative } \\
\text { changes in intervertebral discs } \\
\text { between } 20 \text { and } 45 \text { years old. }\end{array}$ & $\begin{array}{l}\text { Breathing } \\
\text { techniques in Yoga. } \\
\mathrm{N}=20\end{array}$ & Control. $\mathrm{N}=20$ & Pain & $4.68+/-2.3$ & $6.1+/-2.19$ & 0.04 \\
\hline $\begin{array}{l}\text { Sagkal, } 2016 \\
\text { (Sagkal \& Ciray, 2016) }\end{array}$ & $\begin{array}{l}\text { Women with cesarean delivery } \\
\text { between the ages of } 18 \text { and } \\
45 \text { who do not use non-opioid } \\
\text { analgesics. }\end{array}$ & Reiki. $N=16$ & Control. $\mathrm{N}=16$ & Pain & $26.8+/-21.3$ & $37.2+/-19.1$ & 0.001 \\
\hline $\begin{array}{l}\text { Larkey, } 2016 \\
\text { (Larkey et al., 2016) }\end{array}$ & $\begin{array}{l}\text { Women diagnosed with stage } \\
\text { 0-III breast cancer }\end{array}$ & $\begin{array}{l}\text { Breathing } \\
\text { techniques with } \\
\text { Tai-Chi and } \\
\text { Qigong.N = } 49\end{array}$ & Control. $\mathrm{N}=52$ & $\begin{array}{l}\text { Cognitive function. } \\
\text { FACT- Cog PCI }\end{array}$ & $1.01+/-0.75$ & $1.1+/-0.66$ & NS \\
\hline
\end{tabular}

NS: Not Significant. 


\section{Studies excluded}

Out of the articles reviewed in full text, 13 of these were excluded, the most frequent reason for exclusion was that these articles did not assess pain or cognitive function (See Table 2).

\section{Risk of bias of included studies}

The studies in general had an intermediate risk of bias (See Figure 2), this classification is due to the lack of blinding in some studies, specifically the blinding of the personnel evaluating the patients and the unclear risk of bias for the concealment of random assignment (See Figure 3).

Some studies had an unclear risk of bias in the generation of the random sequence secondary to the mention of the method, but how this sequence is performed is not explained (Grubić et al., 2019; Park \& Lee, 2019; Phattharasupharerk et al., 2019; Telles et al., 2016; Wongwilairat et al., 2018) (See Figure 3).

TABLE 2.

Excluded articles

\begin{tabular}{ll}
\hline \multicolumn{1}{c}{ Reference } & \multicolumn{1}{c}{ Reason for exclusion } \\
\hline Frøkjær 2016 (Frokjaer et al., 2016) & Different outcome \\
Pettersson 2015 (Pettersson, Faager \& Westerdahl, 2015) & Different outcome \\
Telles 2016 (Telles et al., 2016) & Different outcome \\
Rietberg 2017 (Rietberg, Veerbeek, Gosselink, Kwakkel \& van Wegen, 2017) & Literature review \\
Smith 2015 (Smith et al., 2015) & Literature review \\
Janssens 2015 (Janssens et al., 2015) & Different intervention \\
Gunay 2016 (Gunay et al., 2016) & Different outcome \\
Nyer 2018 (Nyer et al., 2018) & Different outcome \\
Patrician 2019 (Patrician et al., 2019) & Different outcome \\
Smith 2017 (Smith \& Norman, 2017) & It is not a clinical trial \\
Ratcliff 2018 (Ratcliff et al., 2019) & Different intervention \\
Seyyed-Rasooli 2016 (Seyyed-Rasooli et al., 2016) & Different intervention \\
\hline
\end{tabular}

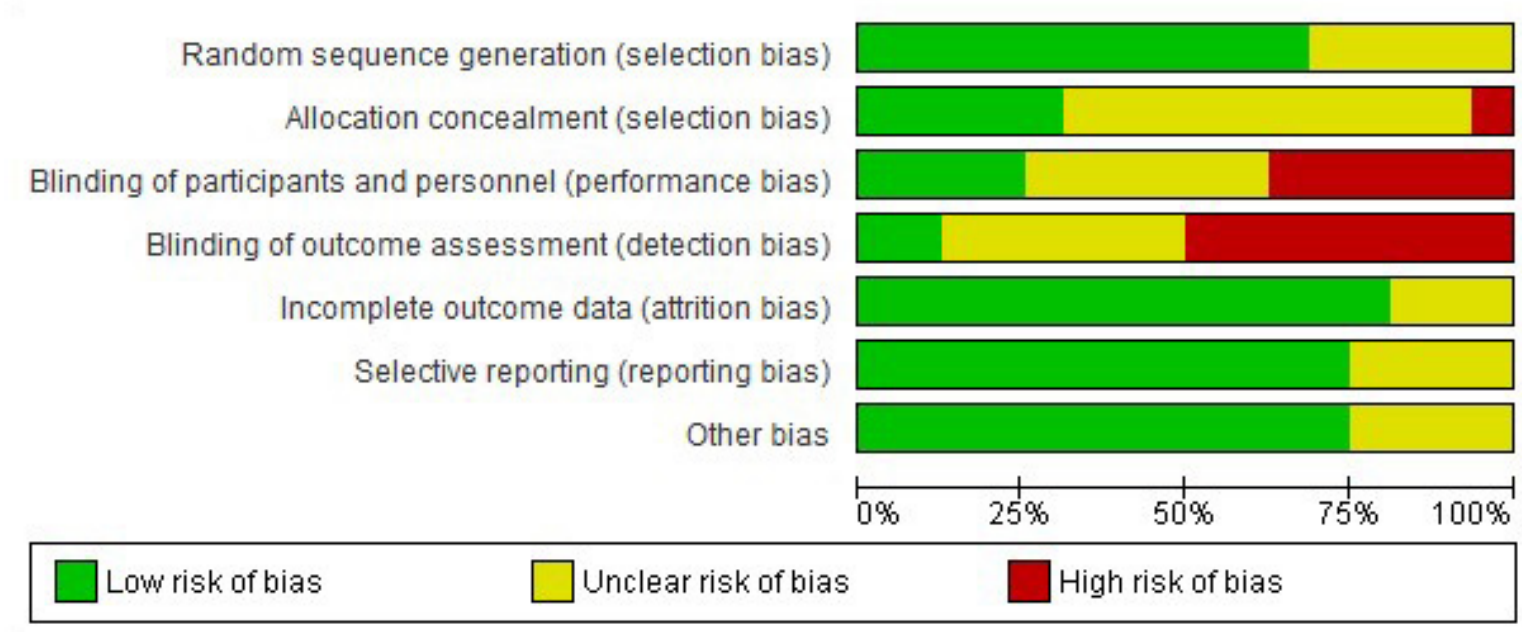

Figure 2. Summary of risk of bias. 


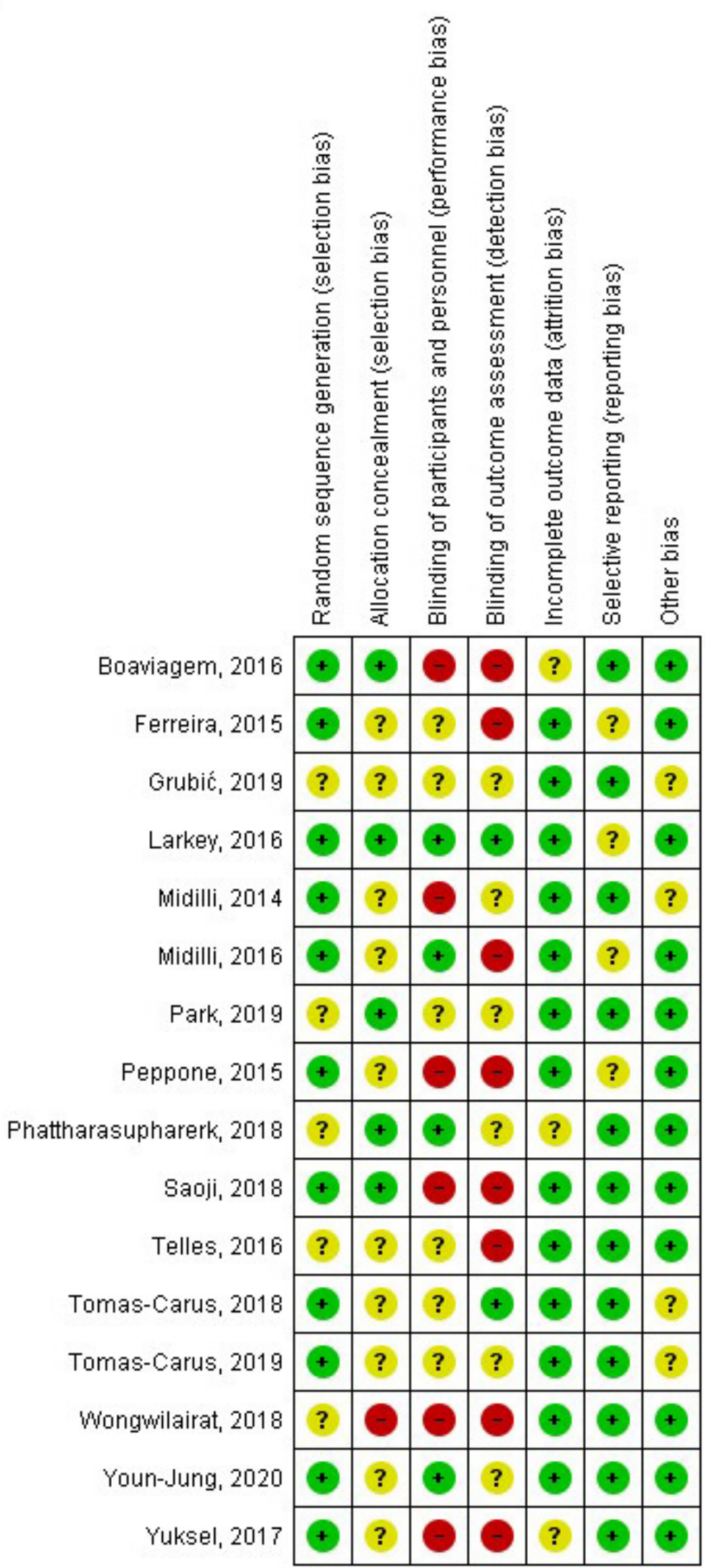

Figure 3. Risk of bias of included studies.

\section{Effects of interventions}

The results of each study are presented below (See Table 1).

\section{Pain}

\section{Breathing techniques in pregnant patients}

The Boaviagem in 2016 study (Boaviagem et al., 2017) included women in labor between 12 to 40 years of age and evaluated the efficacy of breathing patterns during the active phase of the first stage of labor. The study did not find statistically significant differences between the intervention and the control for pain measured with the visual analog scale $(8.8+/-0.3$ vs $8.8+/-0.3)$.

Following the line of studies in pregnant women, the study by Yuksel 2017 (Yuksel et al., 2017) evaluated a controlled breathing method in pregnant women between 37 and 42 weeks. Patients in the intervention group received a respiratory exercise session in the first stage of labor. During training, all participants performed abdominal breathing during the second stage of labor. The main components of the breathing exercises were:

a. First, fill your stomach and then your lungs with air as you inhale;

b. Feel the expansion in your stomach;

c. Make sure the muscles from the stomach to the knee are relaxed, as if you were urinating while exhaling;

d. When there is pain, do deep abdominal breathing exercises, take a deep breath and hold as much as you can;

e. Try to push the baby down;

f. You can do this by holding your breath or exhaling very slowly through your mouth;

g. The most important point at this stage is that you do not have to fill your stomach with air, and you must push down to deliver the baby;

h. You should continue pushing until the pain is relieved. 
When evaluating maternal pain with the visual analog scale, statistically significant differences were found $(88.2+/-6.3$ vs $90.5+/-7$, p-value $=0.0001)$.

Similarly, Sagkal \& Eser (2015) included 29 women with cesarean delivery between 18 and 45 years of age who did not use non-opioid analgesics, comparing Reiki vs control, finding a decrease in pain in terms of the visual analog scale $(1.24+/-0.99 \mathrm{vs}$ $3.76+/$ - 1.61, p-value 0.001).

\section{Breathing techniques in other entities}

The study by Tomas-Carus et al. (2018) included women with fibromyalgia and compared a respiratory exercise program versus a control. The respiratory exercise program consisted of $30 \mathrm{~min} /$ session for 7 times/ week for 12 weeks: 1 time supervised by an expert in breathing exercises, and 6 times/ week without supervision at home with audiovisual training through a versatile digital disc. Each session focused on breathing exercises that strengthened and lengthened the skeletal muscles of the thorax and abdomen, including five breathing exercises (3 min for each one), which were performed in the form of a circuit ( 2 circuits/session), including, a breathing awareness exercise: in a supine position, inhale through the nose and exhale through the mouth with the lips parted slowly; rib expansion exercise: in supine position, with the arms along the body with a cane held by the hands. Raise your arms and inhale and exhale and lower your arms; and three diaphragmatic breathing exercises: exercise (1) in the supine position, overlapping the hands on the diaphragm located in the abdominal region: breathe in through your nose and breathe out through your mouth slowly with your lips parted; exercise (2) in the prone position, with a folded towel under the diaphragm located in the abdominal region: breathe in through your nose and breathe out through your mouth slowly with your lips half closed; and exercise (3) in supine position, with a weight of $1 \mathrm{~kg}$ on the diaphragm located in the abdominal region: breathe in through the nose and exhale through the mouth slowly with the lips parted. The authors found statistically significant differences between the intervention and the control in pain measured by the visual analog scale (5.8 vs 7.9 , pvalue 0.025$)$. The same author presented a similar study one year later (TomasCarus et al., 2019), where they also found no statistically significant differences in terms of pain measured by the visual analog scale.

Wongwilairat et al. (2018) included women with tension neck pain between 20 and 25 years of age with normal BMI, compared slow and deep breathing exercise vs other breathing methods, finding no statistically significant differences when measuring pain with the visual analog scale $(0.75+/-0.71$ vs $0.75+/$-1.49).

On the other hand, Grubić et al. (2019) evaluated breathing exercises at home vs a control in patients with multiple sclerosis. For the breathing exercises, the basic principle was to inhale and exhale as fully as possible, but slowly to avoid hyperventilation and dizziness. Diaphragmatic or abdominal breathing (1.5 min) was performed to strengthen the abdominal muscles and the diaphragm, and thoracic breathing (1.5 min) to strengthen the intercostal muscles $(3 \times-20$-s pause- $3 \times)$. When evaluating pain according to SF36, statistically significant differences were not found. 


\section{Qigong}

Park \& Lee (2019) included patients with low back pain between 18 and 65 years old with pain of at least 6 weeks of progress and compared a respiratory resistance training vs a control evaluating pain with the visual analog scale, the authors found no differences statistically significant. Another similar study in women with low back pain (Oh et al., 2020) evaluated abdominal breathing maneuvers, finding no statistical differences between the groups. On the other hand, Phattharasupharerk et al. (2019) included office workers with non-specific low back pain of at least 12 weeks between 20 and 40 years of age. He compared Qigong vs control group. The Qigong group participants received an hour Qigong practice session each week for six weeks (Guan Yin Zi Zai Gong level 1, developed by Yang Pei Xen since 1995) at their workstation by a professional Qigong instructor from the Master Yang Qigong Center, Bangkok, Thailand. Fifteen minutes of Wu Chi meditation and 28 minutes of static exercise. In the pain outcome, the authors found statistically significant differences $(14+/$-20.5 vs $53.5+/$ - 20.9, p-value: 0.001$)$.

\section{Yoga-based breathing techniques}

Peppone et al. (2015) included women survivors of cancer 2 to 24 months after surgery, compared YOCAS vs control. The intervention includes 16 poses sitting, standing, transitional and supine. Breathing exercises includes low, controlled, diaphragmatic work of breathing coordinated by movements. Mindfulness exercises include meditation, visualization, and affirmation activities. The intervention is delivered in a group format taught by an instructor, twice a week, for 75 minutes each time, for 4 weeks which means a total of eight yoga sessions. Pain was evaluated using the FACIT F-I scale, finding statistical differences ( $p$-value 0.021). In the same line of breathing techniques based on Yoga (Telles et al., 2016) used these techniques in people with degenerative changes in intervertebral discs between 20 and 45 years old, finding differences in the measurement of pain with the use of the visual analog scale $(4.68+/-2.63$ vs $6.1+/-2.19$, p-value 0.04 ).

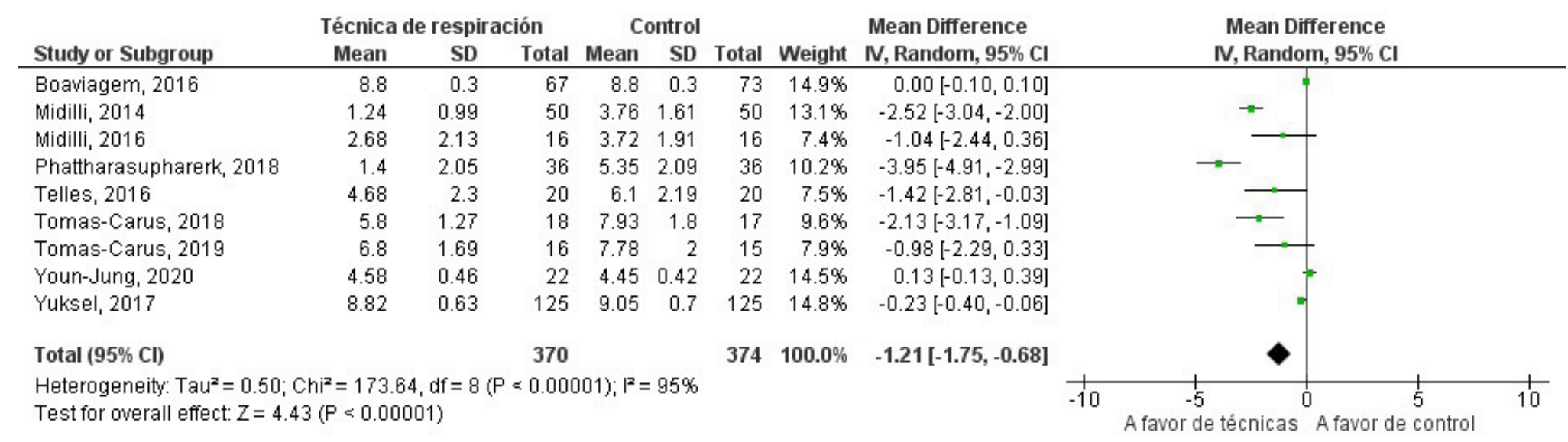

Figure 4. Meta-analysis of pain, breathing techniques vs. control. 


\section{Combination of studies}

When combining the different breathing techniques vs control in the included studies, we found a statistically significant difference in terms of the visual analog scale (Difference of means, random effects; -1.21 [95\% CI -1.75 to -0.68]; I2: 95\%).

\section{Cognitive function}

Three studies that measured cognitive function were included, one of these (Saoji et al., 2018) included healthy volunteers in yoga courses and compared breathing techniques derived from yoga vs. control, finding statistically significant differences with the scales used (See Table 1). The second study (Ferreira et al., 2015) found statistical differences in terms of semantic memory, mental manipulation, abstraction and mental flexibility when comparing breathing training vs social interaction in adults between 60 and 79 years old. The last of the studies did not find statistically significant differences in terms of cognitive function with the FACT-COG PCI scale when comparing breathing techniques with Tai-Chi and Qugong vs control in women diagnosed with breast cancer (See Table 1).

\section{Discussion}

An improvement in pain and cognitive function in intervention was found in most of the included studies in terms of breathing techniques accompanied by abstraction of ideas or the use of thoughts during the process of the same. This does not occur with studies that exclusively include breathing techniques.
The present findings appear to be consistent with other studies, which found that breathing techniques could reduce short-term and long-term pain intensity. It seems possible that these results are given because some techniques consist of three elements that could reduce pain: posture, deep breathing and meditation. The breathing techniques comprised various poses and movements that could strengthen the stabilizing muscles of the core. Also, deep breathing and meditation on breathing techniques help relax the body and mind, which in turn reduces muscle activity. In addition, meditation reduces the perception of pain (Abdallah et al., 2018; Abedi, Jahanfar, Namvar \& Lee, 2016; Altenau, Crisp, Devaiah, \& Lambers, 2017). A previous study by Sharon et al. (2016) demonstrated that meditation significantly reduces pain and cold stimulus-induced pain discomfort score in healthy adults. Interestingly, intravenous injection of naloxone, an opioid blocker, reverses this analgesic effect of meditation, suggesting that meditation modulates pain through the endogenous opioid mechanism (Sharon et al., 2016). Furthermore, a previous study by Movahedi, Ghafari, Nazari \& Valiani (2017) showed that acupressure to specific points 3 times a week for three weeks reduced the severity of chronic low back pain (Babina, Mohanty \& Pattnaik, 2016; Barnes, McDonald, Smallwood, \& Manser, 2019; Bayer et al., 2017).

A previous study showed that Qigong practice reduced stress and increased social interaction in the hospital staff (Knips et al., 2019; Larkey et al., 2016; Phattharasupharerk et al., 2019). Similarly, Skoglund y Jansson (2007) showed 
that Qigong practice reduced the symptoms of low back pain and stress by reducing sympathetic activity. The results of this study showed that breathing exercises significantly reduced heart rate and respiratory rate compared to the reference and waiting list group. During meditation, the body enters a state of relaxation response by decreasing heart rate, respiratory rate, blood pressure, and muscle tone and increasing alpha brain waves, which in turn reduces stress (Lee, Gordon \& Osadnik, 2018; Lee et al., 2016; Lee \& Jang, 2019).

Among the limitations of this review, the small sample size of the included studies, is found, as well as the fact that several of these interventions were performed in an unsupervised manner and had short followup periods. On the other hand, the studies found are very heterogeneous clinically and statistically with each other; therefore, the combination of studies should be interpreted with caution and future studies could modify the interpretation of these results.

It is therefore suggested that randomized studies be carried out with sample sizes greater than those found in this review.We conclude then that meditationbased breathing techniques would improve pain and cognitive function in patients with a painful entity or healthy volunteers.

\section{REFERENCES}

Aamann, L., Dam, G., Rinnov, A. R., Vilstrup, H. \& Gluud, L. L. (2018). Physical exercise for people with cirrhosis. Cochrane Database of Systematic Reviews, (12), 1-42. https:// doi.org/10.1002/14651858.cd012678. pub2
Abdallah, S. J., Smith, B. M., Ware, M. A., Moore, M., Li, P. Z., Bourbeau, J. \& Jensen, D. (2018). Effect of Vaporized Cannabis on Exertional Breathlessness and Exercise Endurance in Advanced Chronic Obstructive Pulmonary Disease. A Randomized Controlled Trial. Annals of the American Thoracic Society, 15(10), 1146-1158. https://doi. org/10.1513/AnnalsATS.2018031980C

Abedi, P., Jahanfar, S., Namvar, F. \& Lee, J. (2016). Breastfeeding or nipple stimulation for reducing postpartum haemorrhage in the third stage of labour. Cochrane Database of Systematic Reviews, (1), 1-32. https:// doi.org/10.1002/14651858.CD010845. pub2

Altenau, B., Crisp, C. C., Devaiah, C. G. \& Lambers, D. S. (2017). Randomized controlled trial of intravenous acetaminophen for postcesarean delivery pain control. American Journal of Obstetrics \& Gynecology, 217(3), 362.e361-362.e366. https:// doi.org/10.1016/j.ajog.2017.04.030

Arsenault, M., Ladouceur, A., Lehmann, A., Rainville, P. \& Piché, M. (2013). Pain modulation induced by respiration: phase and frequency effects. Neuroscience, 12(252), 501511. https://doi.org/10.1016/j.neuroscience.2013.07.048

Babina, R., Mohanty, P. P. \& Pattnaik, M. (2016). Effect of thoracic mobilization on respiratory parameters in chronic non-specific low back pain: A randomized controlled trial. Journal of Back \& Musculoskeletal Rehabilitation, 29(3), 587-595. https://doi. org/10.3233/BMR-160679 
Barnes, H., McDonald, J., Smallwood, N. \& Manser, R. (2019). Opioids for the palliation of refractory breathlessness in adults with advanced disease and terminal illness. Cochrane Database of Systematic Reviews, (3), 1-103. https://doi.org/10.1002/14651858. CD011008.pub2

Bayer, U., Glazachev, O. S., Likar, R., Burtscher, M., Kofler, W., Pinter, G., Stettner, H., Demschar, S., Trummer, B. \& Neuwersch, S. (2017). [Adaptation to intermittent hypoxia-hyperoxia improves cognitive performance and exercise tolerance in elderly]. Advances in Gerontology, 7(3), 214-220. https:// doi.org/10.1134/S2079057017030031

Boaviagem, A., Melo Junior, E., Lubambo, L., Sousa, P., Aragao, C., Albuquerque, S. \& Lemos, A. (2017). The effectiveness of breathing patterns to control maternal anxiety during the first period of labor: A randomized controlled clinical trial. Complementary Therapies in Clinical Practice, 26, 30-35. https://doi.org/10.1016/j. ctcp.2016.11.004

Chan, K. K., Joo, D. A., McRae, A. D., Takwoingi, Y., Premji, Z. A., Lang, E. \& Wakai, A. (2019). Chest ultrasonography versus supine chest radiography for diagnosis of pneumothorax in trauma patients in the emergency department. Cochrane Database of Systematic Reviews, (5), 1-16. https:// doi.org/10.1002/14651858.CD013031. pub2

Choo, J. K., Simons, E. F. \& Sheikh, A. (2018). Glucocorticoids for the treatment of anaphylaxis. Cochrane Database of Systematic Reviews, 65(10), 1205-1211. https://doi.org/10.1111/ j.1398-9995.2010.02424.x
Connolly, B., Salisbury, L., O’Neill, B., Geneen, L. J., Douiri, A., Grocott, P. W. M., Hart, N., Walsh, T. \& Blackwood, B. (2018). Exercise rehabilitation following intensive care unit discharge for recovery from critical illness. Journal of Cachexia, Sarcopenia and Muscle, (7) 1-6. https://doi.org/10.1002/ jcsm.12146

Ferreira, L., Tanaka, K., Santos-Galduroz, R. F. \& Fernandes, J. C. (2015). Respiratory training as strategy to prevent cognitive decline in aging: a randomized controlled trial. Clinical Interventions in Aging, (10), 593-603. https://doi.org/10.2147/CIA.S79560

Frokjaer, J. B., Bergmann, S., Brock, C., Madzak, A., Farmer, A. D., Ellrich, J. \& Drewes, A. M. (2016). Modulation of vagal tone enhances gastroduodenal motility and reduces somatic pain sensitivity. Neurogastroenterology \& Motility, 28(4), 592-598. https://doi. org/10.1111/nmo.12760

Gilbert-Kawai, E. T., Mitchell, K., Martin, D., Carlisle, J. \& Grocott, P. W. M. (2018). Permissive hypoxaemia versus normoxaemia for mechanically ventilated critically ill patients. Cochrane Database of Systematic Reviews, (5), 1-18.https://doi.org/10.1002/14651858. CD009931.pub2

Grubić, T., Babić, M. \& Štimac, D. (2019). Exploring the feasibility of a mild and short 4-week combined upper limb and breathing exercise program as a possible home base program to decrease fatigue and improve quality of life in ambulatory and non-ambulatory multiple sclerosis individuals. Neurological Sciences, 40(4), 733-743. https:// doi.org/10.1007/s10072-019-3707-0 
Gunay, S., Eser, I., Ozbey, M., Agar, M., Koruk, I. \& Kurkcuoglu, I. C. (2016). Evaluation of two different respiratory physiotherapy methods after thoracoscopy with regard to arterial blood gas, respiratory function test, number of days until discharge, cost analysis, comfort and pain control. Nigerian Journal of Clinical Practice, 19(3), 353358. https://doi.org/10.4103/11193077.179279

Janssens, L., McConnell, A. K., Pijnenburg, M., Claeys, K., Goossens, N., Lysens, R., Troosters, T. \& Brumagne, S. (2015). Inspiratory muscle training affects proprioceptive use and low back pain. Medicine \& Science in Sports \& Exercise, 47(1), 12-19. https://doi.org/10.1249/ MSS.0000000000000385

Knips, L., Bergenthal, N., Streckmann, F., Monsef, I., Elter, T. \& Skoetz, N. (2019). Aerobic physical exercise for adult patients with haematological malignancies. Cochrane Database of Systematic Reviews, (1), 1-104. https://doi.org/10.1002/14651858. CD009075.pub3

Larkey, L. K., Roe, D. J., Smith, L. \& Millstine, D. (2016). Exploratory outcome assessment of Qigong/Tai Chi Easy on breast cancer survivors. Complementary Therapies in Medicine, 29, 196-203. https://doi.org/10.1016/j. ctim.2016.10.006

Lee, A. L., Gordon, C. S. \& Osadnik, C. R. (2018). Exercise training for bronchiectasis. Cochrane Database of Systematic Reviews, (8), 1-12. https://doi.org/10.1002/14651858. CD013110
Lee, J. M., Lee, S. K., Lee, S. J., Hwang, W. S., Jang, S. W. \& Park, E. Y. (2016). Comparison of remifentanil with dexmedetomidine for monitored anaesthesia care in elderly patients during vertebroplasty and kyphoplasty. Journal of International Medical Research, 44(2), 307-316. https://doi. org/10.1177/0300060515607385

Lee, M.-H. \& Jang, S.-H. (2019). The effects of the neck stabilization exercise on the muscle activity of trunk respiratory muscles and maximum voluntary ventilation of chronic stroke patients. Journal of Back \& Musculoskeletal Rehabilitation, 32(6), 863868. https://doi.org/10.3233/BMR170839

Lewis, S. R., Nicholson, A., Reed, S. S., Kenth, J. J., Alderson, P. \& Smith, A. F. (2019). Anaesthetic and sedative agents used for electrical cardioversion. Cochrane Database of Systematic Reviews, (3), 1-78. https:// doi.org/10.1002/14651858.CD010824. pub2

Mah, G. T., Turgeon, R. D., Loh, G., Tejani, A. M. \& Sweet, D. D. (2019). Ketamine and propofol in combination for adult procedural sedation and analgesia in the emergency department. Cochrane Database of Systematic Reviews, (1). 1-21. https://doi. org/10.1002/14651858.CD011456

Mesgarpour, B., Heidinger, B. H., Roth, D., Schmitz, S., Walsh, C. D. \& Herkner, H. (2019). Harms of off-label erythropoiesis-stimulating agents for critically ill people. Cochrane Database of Systematic Reviews, (8), 1-196. https://doi.org/10.1002/14651858. cd010969.pub2 
Movahedi, M., Ghafari, S., Nazari, F. \& Valiani, M. (2017). The effects of acupressure on pain severity in female nurses with chronic low back pain. Iranian journal of nursing and midwifery research, 22(5), 339-342. https://doi. org/10.4103/ijnmr.IJNMR_108_16

Nyer, M., Gerbarg, P., Silveri, M., Johnston, J., Scott, T., Nauphal, M., Owen, L., Nielsen, G., Mischoulon, D., Brown, R., Fava, M. \& Streeter, C. (2018). A randomized controlled dosing study of Iyengar yoga and coherent breathing for the treatment of major depressive disorder: Impact on suicidal ideation and safety findings. Complementary Therapies in Medicine, 37, 136-142. https:// doi.org/10.1016/j.ctim.2018.02.006

Oh, Y.-J., Park, S.-H. \& Lee, M.-M. (2020). Comparison of Effects of Abdominal Draw-In Lumbar Stabilization Exercises with and without Respiratory Resistance on Women with Low Back Pain: A Randomized Controlled Trial. Medical Science Monitor, 26, e9212951-e921295-8. https://doi.org/10.12659/ MSM.921295

Park, S.-H. \& Lee, M.-M. (2019). Effects of a Progressive Stabilization Exercise Program Using Respiratory Resistance for Patients with Lumbar Instability: A Randomized Controlled Trial. Medical Science Monitor, 25, 1740-1748. https:// doi.org/10.12659/MSM.913036

Patrician, A., Tymko, M. M., Caldwell, H. G., Howe, C. A., Coombs, G. B., Stone, R., Hamilton, A., Hoiland, R. L. \& Ainslie, P. N. (2019). The Effect of an Expiratory Resistance Mask with Dead Space on Sleep, Acute Mountain Sickness, Cognition, and Ventilatory Acclimatization in Normobaric Hypoxia. High Altitude Medicine \& Biology, 20(1), 61-70. https://doi.org/10.1089/ham.2018.0074
Peppone, L. J., Janelsins, M. C., Kamen, C., Mohile, S. G., Sprod, L. K., Gewandter, J. S., Kirshner, J. J., Gaur, R., Ruzich, J., Esparaz, B. T. \& Mustian, K. M. (2015). The effect of YOCASC R yoga for musculoskeletal symptoms among breast cancer survivors on hormonal therapy. Breast Cancer Research \& Treatment, 150(3), 597-604. https:// doi.org/10.1007/s10549-015-3351-1

Pettersson, H., Faager, G. \& Westerdahl, E. (2015). Improved oxygenation during standing performance of deep breathing exercises with positive expiratory pressure after cardiac surgery: A randomized controlled trial. Journal of Rehabilitation Medicine, 47(8), 748752. https://doi.org/10.2340/165019771992

Phattharasupharerk, S., Purepong, N., Eksakulkla, S. \& Siriphorn, A. (2019). Effects of Qigong practice in office workers with chronic non-specific low back pain: A randomized control trial. Journal of Bodywork \& Movement Therapies, 23(2), 375-381. https://doi. org/10.1016/j.jbmt.2018.02.004

Pollok, J., van Agteren, J. E. M. \& CarsonChahhoud, K. V. (2018). Pharmacological interventions for the treatment of depression in chronic obstructive pulmonary disease. Cochrane Database of Systematic Reviews, (12), 1-53. https:// doi.org/10.1002/14651858.CD012346. pub2

Ratcliff, C. G., Prinsloo, S., Chaoul, A., Zepeda, S. G., Cannon, R., Spelman, A., Yang, W. T. \& Cohen, L. (2019). A Randomized Controlled Trial of Brief Mindfulness Meditation for Women Undergoing Stereotactic Breast Biopsy. Journal of the American College of Radiology, 16(5), 691-699. https://doi. org/10.1016/j.jacr.2018.09.009 
Rietberg, M. B., Veerbeek, J. M., Gosselink, R., Kwakkel, G. \& van Wegen, E. E. H. (2017). Respiratory muscle training for multiple sclerosis. Cochrane Database of Systematic Reviews, (12), 1-37. https://doi. org/10.1002/14651858.CD009424. pub2

Sagkal, T. \& Ciray, N. (2016). Effects of Reiki on Pain and Vital Signs When Applied to the Incision Area of the Body After Cesarean Section Surgery: A Single-Blinded, Randomized, Double-Controlled Study. Holistic Nursing Practice, 30(6), 368-378. https://doi. org/10.1097/HNP.0000000000000172

Sagkal, T. S. \& Eser, I. (2015). Effects of Reiki on Post-cesarean Delivery Pain, Anxiety, and Hemodynamic Parameters: A Randomized, Controlled Clinical Trial. Pain Management Nursing, 16(3), 388-399. https://doi. org/10.1016/j.pmn.2014.09.005

Saoji, A. A., Raghavendra, B. R., Madle, K. \& Manjunath, N. K. (2018). Additional Practice of Yoga Breathing With Intermittent Breath Holding Enhances Psychological Functions in Yoga Practitioners: A Randomized Controlled Trial. Explore: The Journal of Science \& Healing, 14(5), 379-384. https://doi.org/10.1016/j.explore.2018.02.005

Seyyed-Rasooli, A., Salehi, F., Mohammadpoorasl, A., Goljaryan, S., Seyyedi, Z. \& Thomson, B. (2016). Comparing the effects of aromatherapy massage and inhalation aromatherapy on anxiety and pain in burn patients: A single-blind randomized clinical trial. Burns, 42(8), 1774-1780. https://oi.org/10.1016/j. burns.2016.06.014
Sharon, H., Maron-Katz, A., Ben-Simon, E., Flusser, Y., Hendler, T., Tarrasch, R. \& Brill, S. (2016). Mindfulness meditation modulates pain through endogenous opioids. The American Journal of Medicine, 129(7), 755-758. https://doi. org/10.1016/j.amjmed.2016.03.002

Skoglund, L. \& Jansson, E. (2007). Qigong reduces stress in computer operators. Complementary Therapies in Clinical Practice, 13(2), 78-84. https://doi. org/10.1016/j.ctcp.2006.09.003

Smith, K. E. \& Norman, G. J. (2017). Brief relaxation training is not sufficient to alter tolerance to experimental pain in novices. PLoS ONE, 12(5), 1-13. https:// doi.org/10.1371/journal.pone.0177228

Smith, S. R., Draganic, B., Pockney, P., Holz, P., Holmes, R., McManus, B. \& Carroll, R. (2015). Transversus abdominis plane blockade in laparoscopic colorectal surgery: a double-blind randomized clinical trial. International Journal of Colorectal Disease, 30(9), 1237-1245. https:// doi.org/10.1007/s00384-015-2286-7

Sud, S., Sud, M., Friedrich, J. O., Wunsch, H., Meade, M. O., Ferguson, N. D. \& Adhikari, K. J. N. (2018). High-frequency oscillatory ventilation versus conventional ventilation for acute respiratory distress syndrome. Cochrane Database of Systematic Reviews, (4). 1-49. https:// doi.org/10.1002/14651858.CD004085. pub4

Telles, S., Bhardwaj, A. K., Gupta, R. K., Sharma, S. K., Monro, R. \& Balkrishna, A. (2016). A Randomized Controlled Trial to Assess Pain and Magnetic Resonance Imaging-Based (MRI-Based) Structural Spine Changes in Low Back Pain Patients After Yoga Practice. Medical Science Monitor, 22, 3228-3247. https://doi.org/10.12659/MSM.896599 
Telles, S., Sharma, S. K., Gupta, R. K., Bhardwaj, A. K. \& Balkrishna, A. (2016). Heart rate variability in chronic low back pain patients randomized to yoga or standard care. BMC Complementary \& Alternative Medicine, 16(1), 279. https://doi. org/10.1186/s12906-016-1271-1

Tomas-Carus, P., Branco, J. C., Raimundo, A., Parraca, J. A., Batalha, N. \& Biehl-Printes, C. (2018). Breathing Exercises Must Be a Real and Effective Intervention to Consider in Women with Fibromyalgia: A Pilot Randomized Controlled Trial. Journal of Alternative \& Complementary Medicine, 24(8), 825-832. https:// doi.org/10.1089/acm.2017.0335

Tomas-Carus, P., Garrido, M., Branco, J. C., Castano, M. Y., Gomez, M. A. \& Biehl-Printes, C. (2019). Non-supervised breathing exercise regimen in women with fibromyalgia: A quasi-experimental exploratory study. Complementary Therapies in Clinical Practice, 35, 170-176. https://doi. org/10.1016/j.ctcp.2019.02.006

Vojislav, M., Ramanathana, D. \& Mishraa, J. (2020). Respiratory regulation \& interactions with neurocognitive circuitry. Neuroscience \& Biobehavioral Reviews, 112, 95106. https://doi.org/10.1016/j.neubiorev.2020.02.001

Wall, B. F., Magee, K., Campbell, S. G. \& Zed, P. J. (2019). Capnography versus standard monitoring for emergency department procedural sedation and analgesia. Cochrane Database of Systematic Reviews, (3), 1-42. https://doi.org/10.1002/14651858. CD010698.pub2
Warttig, S., Alderson, P., Evans, J. W. D., Lewis, S. R., Kourbeti, I. S. \& Smith, A. F. (2019). Automated monitoring compared to standard care for the early detection of sepsis in critically ill patients. Cochrane Database of Systematic Reviews, (6), 1-25. https://doi. org/10.1002/14651858.CD012404.pub2

Wongwilairat, K., Buranruk, O., Eungpinichpong, W., Puntumetakul, R. \& Kantharadussadee-Triamchaisri, S. (2018). Muscle stretching with deep and slow breathing patterns: a pilot study for therapeutic development. Journal of Complementary \& Integrative Medicine, 16(2), 1-9. https://doi. org/10.1515/jcim-2017-0167

Yuksel, H., Cayir, Y., Kosan, Z. \& Tastan, K. (2017). Effectiveness of breathing exercises during the second stage of labor on labor pain and duration: a randomized controlled trial. The Journal of Integrative Medicine, 15(6), 456461. https://doi.org/10.1016/S20954964(17)60368-6

Zhang, W. H., Zhang, H., Grant, S. J., Wan, X. \& Li, G. (2018). Single herbal medicine for diabetic retinopathy. Cochrane Database of Systematic Reviews, (12), 1-41. https://doi. org/10.1002/14651858.CD007939.pub2

Armando Solarte: Medical surgeon from the Universidad de Caldas (Colombia).

Juan Pablo Alzate-Granados: Master in Clinical Epidemiology from the UNAL (Colombia).

Pedro Javier López-Pérez: Doctorate in Experimental Psychology from Universidad de la Laguna (Spain).

Barceló Ernesto: MD. D. Medical Doctor from Universidad del Norte (Colombia). 


\section{APPENDIX 1. \\ Search strategy}

Respiration/ respirat*.tw

Breathing.tw

Breathing Exercises/

Respiratory Mechanics/

Respiratory Rate/

Inhalation/

Inhaling.tw

Inspiration.tw

Exhalation/

Exhalation.tw

Expiration.tw

Exhaling.tw

Pain, Referred/

Pain.tw

Flank Pain/

Neck Pain/

Neck Aches.tw

Cervicalgia.tw

Pelvic Pain/

Low Back Pain/

Lumbago.tw

Abdominal Pain/

Colicky Pain.tw

Pain Measurement/

Analgesia Test.tw

Chest Pain/

Back Pain/

Backache.tw

Cancer Pain/

Headache/

Headache.tw

Cephalgia.tw

Hemicrania.tw

Myalgia.tw

Muscle Soreness.tw

Arthralgia/

Arthralgia.tw

Polyarthralgia.tw

Fibromyalgia/

Fibromyalgia.tw

Pain/

Ache.tw

Pain Management.tw

Acute Pain/

Musculoskeletal Pain/

Chronic Pain/

Nociceptive Pain/

Cognition/

Cognition.tw

Cognitive Function.tw

Neuropsychological Tests/

Neuropsychologic Test.tw

Source: Author. 